\title{
CRYSTAL STRUCTURE OF BIS(4,4'-BIPYRIDINE)ZINC(II) SUCCINATE
}

\author{
Jun Tao', Yue-Li Fu' ${ }^{1}$, Shao-Liang Zheng ${ }^{1}$, Xiao-Ming Chen ${ }^{1}$ and Seik Weng Ng*2 \\ 'School of Chemistry and Chemical Engineering, Zhongshan University, 510275 Guangzhou, China \\ ${ }^{2}$ Institute of Postgraduate Studies, University of Malaya, 50603 Kuala Lumpur, Malaysia
}

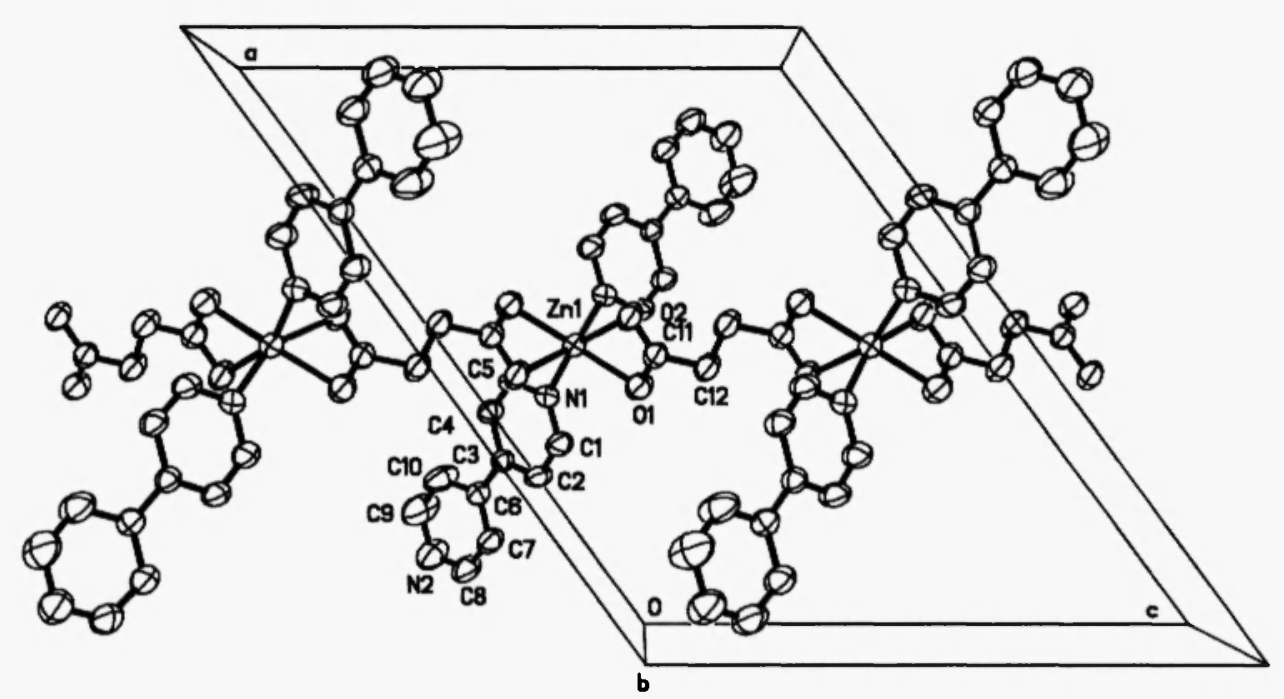

Figure 1. ORTEP plot of the title complex at the $50 \%$ probability level. Selected bond distances and angles: $\mathrm{Zn} 1-\mathrm{Ol}=2.064(2), \mathrm{Zn1}-\mathrm{O} 2=2.317(2), \mathrm{ZnI}-\mathrm{Nl}=2.106(2) \AA ; \mathrm{Ol}-\mathrm{Zn}-\mathrm{Ol} 1^{i}=154.9(1), \mathrm{O} 1-\mathrm{Zn} 1-\mathrm{O} 2$ $=59.7(1), \mathrm{O} 1-\mathrm{ZnI}-\mathrm{O} 2^{1}=101.5(1), \mathrm{O} 1-\mathrm{ZnI}-\mathrm{Nl}=96.4(1), \mathrm{O} 1-\mathrm{Zn} 1-\mathrm{N}^{i}=100.3(1), \mathrm{N} 1-\mathrm{Zn} 1-\mathrm{N}^{\mathrm{i}}=96.4(1)$, $\mathrm{N} 1-\mathrm{Zn} 1-\mathrm{O} 2=155.9(1), \mathrm{N} 1-\mathrm{Zn} 1-\mathrm{O}^{1}=91.5(9), \mathrm{O} 2-\mathrm{Zn} 1-\mathrm{O}^{\mathrm{i}}=90.5(1)^{\circ}$. Symmetry transformation: $i=-x, y$, $0.5-z$.

Table 1. Crystal data for $4,4^{\prime}$-bipyridinezinc(II) succinate

\begin{tabular}{llll}
\hline Empirical formula & $\mathrm{C}_{24} \mathrm{H}_{20} \mathrm{~N}_{4} \mathrm{O}_{4} \mathrm{Zn}$ & Formula weight & 493.81 \\
Crystal system & Monoclinic & Space group & $C 2 / c$ \\
Unit cell dimensions & $a=18.877(10)$ & $\beta$ & $125.99(1)^{\circ}$ \\
& $b=9.915(9)$ & Volume & $2238(2) \AA^{3}$ \\
& $c=14.776(5) \AA$ & $Z$ & 4 \\
Density, $\mathrm{Mg} \mathrm{m}^{-3}$ & 1.466 & $\mu, \mathrm{mm}^{-1}$ & 1.136 \\
$F(000)$ & 1016 & $\theta$ range of data & $2.5-27.0^{\circ}$ \\
Index ranges & $0 \leq h \leq 24,0 \leq k \leq 12,-18 \leq l \leq 15$ & Reflections collected & 2440 \\
Independent reflections & $1855\left(R_{\text {1nt }}=0.039\right)$ & Completeness of data & $99.6 \%$ \\
Refinement method & Full-matrix least-squares on $F^{2}$ & Data $/$ parameters & $2440 / 150$ \\
$w$ & {$\left[\sigma^{2}+(0.0547 P)^{2}+1.9454 P\right]^{-1}$} & $R($ all data $)$ & 0.096 \\
Goodness-of-fit on $F^{2}$ & 1.02 & Final $R[>2 \sigma(I)]$ & 0.039 \\
Programs & $S H E L X S-97, S H E L X L-97$, & Diff. hole and peak, $e \AA^{-3}$ & $=0.23-0.28$ \\
& $X S C A N S, O R T E P[8-11]$ & $C C D C$ deposition no. & 162192 \\
\hline
\end{tabular}




\section{Comment}

The 4,4'-bipyridine ligand is extensively used to bridge metal atoms in the formation of one-, twoand three-dimensional structures [1-6]. Among their zinc(II) complexes, several monocarboxylate complexes of this heterocyclic $N$-donor ligand adopt one-dimensional chain structures. Few dicarboxylates have been examined [7]. Curiously, the potentially bridging heterocycle is linked to the metal atom through only one of the nitrogen ends in the title compound; the metal atom is chelated by the carboxylate groups of adjacent dianions $[\mathrm{Zn}-\mathrm{O}=2.064(2), 2.317(2) \AA]$. The dicarboxylate ligand, which is located about a crystallographic two-fold axis, acts in the bis-chelate mode to bridge the metal atoms into a linear chain running along the $c$-axis of the unit cell. The six-coordinate octahedral geometry is completed by two bipyridine ligands that are trans-to each other.

\section{Experimental}

The title compound was obtained from a hydrothermal synthesis by reacting zinc nitrate, succinic acid, $4,4^{\prime}$-bipyridine and sodium hydroxide at $180^{\circ} \mathrm{C}$ for 60 hours.

\section{Acknowledgments}

We thank the National Natural Science Foundation of China (Grant No. 29971033) and the University of Malaya (F0758/2001A) for supporting this work. The last author thanks the Third World Academy of Sciences for a travel grant to China.

\section{References}

$1 \quad$ S. R. Batten and R. Robson, Angew. Chem., Int. Ed., 37 (1998) 1460.

2 S. Kitagawa and M. Kondo, Bull. Chem. Soc. Jpn., 71 (1998) 1735.

3 O. M. Yaghi, H. Li, C. Davis, D. Richardson and T. L. Groy, Acc. Chem. Res., 31 (1998) 474.

4 M. Munakata, L. Wu and T. Kuroda-Sowa, Adv. Inorg. Chem., 46 (1999) 173.

5 A. J. Blake, N. R. Champness, P. Hubberstey, W.-S. Li, M. A. Withersby and M. Schröder, Coord. Chem. Rev., 183 (1999) 117.

6 L. R. Macgillivray, R. H. Groeneman and J. L. Atwood, J. Am. Chem. Soc., 120 (1998) 2676.

7 J. Tao, M.-L. Tong and X.-M. Chen, J. Chem. Soc., Dalton Trans., (2000) 3669.

8 Siemens Analytical X-ray Instruments, Inc. XSCANS. Siemens software (1990).

9 C.K. Johnson, ORTEP-II. Report ORNL-5138. Oak Ridge National Laboratory, Oak Ridge, Tennessee, USA (1976).

10 G. M. Sheldrick, SHELXS-97. Program for Crystal Structure Solution. University of Göttingen, Germany (1997).

11 G. M. Sheldrick, SHELXL-97. Program for Crystal Structure Refinement. University of Göttingen, Germany (1997). 